Forthcoming in The American Journal of Comparative Law, vol. 58, no. 4 (2010).

\title{
Mobilizing Law in Contemporary Russia: The Evolution of Disputes Over Home Repair Projects
} by Kathryn Hendley ${ }^{1}$

After decades of prohibitions under state socialism, Russians have embraced home repairs with unbridled passion. An industry survey found that, between 2005 and 2008, more than three-fourths of all Muscovites had undertaken some type of home repair. ${ }^{2}$ Though Moscow's vibrant economy may have resulted in more activity than elsewhere, there is no doubt that the pent-up desire to improve their living conditions has been playing out across Russia. Despite the good intentions with which most home repair projects begin, few are free of conflict. Even when homeowners embark on a project with a clear idea of the desired result, they are not always able to convey their wishes effectively to their contractors. The prospects for a conflictfree experience are dimmer when homeowners are unclear about what they want or when the contractors take advantage of them. The misfortune of these homeowners provides a unique window into the evolution of disputes in post-Soviet Russia. More generally, the analysis of these conflicts allows us to understand the relevance of law in the lives of ordinary Russians.

We know remarkably little about how disputes among ordinary Russians evolve and even less about the role played by law in that process. This article begins to fill that gap. Drawing on six focus groups held during the summer of 2007 that brought together people who had recently undertaken home repairs, I trace their experiences. The 59 participants were involved in 84 discrete home repair projects. I analyze and catalogue their experiences using the conceptual framework developed by Felstiner, Abel, and Sarat (1980-81). They lay out a pyramidal series of transformational processes. The first comes when a person acknowledges the problem to himself, thereby "naming" the experience as injurious. The second arises when the person injured attributes "blame" to a third party. The third occurs when the injured party voices his dissatisfaction to that third party and makes a "claim" for some remedy (pp. 635-636). Each successive stage raises the stakes for proceeding and, not surprisingly, some of those injured will opt out. By shifting the primary focus away from courtroom drama and onto what might be called the natural process of disputes, Feltsiner, et al., redirect our attention onto the forces that tend to facilitate or discourage their transformation. While not denying the importance of the specifics of the dispute itself, including the parties and their relationship with each other, they

${ }^{1}$ Kathryn Hendley is William Voss-Bascom Professor of Law and Political Science, University of Wisconsin-Madison. Thanks are due to Evgeny Finkel for assistance in coding the responses from the focus groups. Financial support for the field research was provided by the National Science Foundation, the National Council for Eurasian and East European Research, and the Graduate School of the University of Wisconsin-Madison. Helpful comments on earlier drafts were provided by Howard Erlanger and Stewart Macaulay.

${ }^{2}$ http://www.gfk.ru/filestore/0047/0014/568/DIY_2009.pdf (accessed on June 17, 2009). 
argue that there may be institutional and social forces at work that affect the willingness of the parties to persevere. In particular, they identify lawyers as the most significant agent of transformation due to their gatekeeper function (p. 645). ${ }^{3}$ Less explicit is the role of law itself as a transformational agent. Yet at every stage, the decision as to whether to continue is inevitably affected by the viability of the underlying legal claim.

The Felstiner-Abel-Sarat framework was, of course, not developed with post-Soviet Russia in mind. It was grounded in U.S. experience and has proven very influential in studies of disputing behavior in the U.S. (e.g., Albiston 2005; Engel and Munger 2003; Ewick and Silbey 1998; Merry 1990). None theless, the basic logic is transferable. ${ }^{4}$ In Russia, just as in the U.S., the disputing process is pyramidal in structure, with inchoate injuries at the base and litigation at the apex. More intriguing than the incidence of naming, blaming, and claiming among my respondents are the reasons for their behavior. Building on the insights of Felstiner, et al., I explore the relevance of the agents of transformation they identify to the Russian context, with a particular emphasis on the extent to which law plays a role in shaping behavior.

The very idea that law could be relevant to the decisions made by ordinary Russians who are engaged in conflicts is controversial. Common wisdom suggests that Russians rarely turn to the legal system for help, preferring instead to work out solutions on their own, which sometimes means resorting to extra-legal solutions that may raise the specter of violence or threats of violence to achieve the desired outcome. Public opinion polls have consistently documented Russians' contempt for the courts and for law more generally. ${ }^{5}$ This disdain has been earned. During the decades of Soviet power, the Communist Party used law in a crudely instrumental fashion, ignoring it when it proved inconvenient and changing it at a whim. Courts were

${ }^{3}$ Kritzer (1990), Eisenberg (1994), and Sarat and Felstiner (1986) confirm the powerful gatekeeping role of lawyers in the U.S. disputing process. Griffiths' work on Dutch lawyers suggests that this insight extends beyond the U.S. (Griffiths 1986).

${ }^{4}$ Engel (2005) used it to study how personal injuries evolve in Thailand; I used it to study the evolution of business disputes in Yeltsin-era Russia (Hendley 2001).

${ }^{5}$ The three primary polling agencies in Russia have explored this question. Though there results differ, they all agree that Russians generally have a low opinion of the courts. The most pessimistic is the Levada Center, which in national surveys fielded from 2001 through 2007 found that only about 1317 percent of Russians fully trusted the courts (http://www.levada.ru/press/2007040901.html, accessed on July 25, 2008). On the positive side, the results have been trending upwards. In a national survey fielded in July 2008, the Foundation for Public Opinion (FOM) found that 28 percent of Russians viewed the activities of the courts as basically positive (http://bd.fom.ru/report/map/d082322, accessed on July 25, 2008). The All-Russian Center for the Study of Public Opinion (VTsIOM) asked the question differently. In a national survey fielded in November 2007, they asked Russians whether they felt that going to court was an effective method of protecting their rights. The results were fairly equally divided. 36 percent responded positively; 38 percent responded negatively; and 23 percent were unable to respond (http://bd.fom.ru/report/map/d082322, accessed on July 25, 2008). 
likewise manipulable by the political elite. This was done most blatantly during the Stalinist purges, when the courts served as conveyor belts to the gulags, but the stranglehold of the Communist Party on the judiciary ensured that outcomes could be predetermined whenever deemed politically necessary. As Feifer (1964) illustrated in his ethnography of the Soviet courts in the 1960s, not all trials were tainted in this way. Indeed, as Sharlet (1977) has argued, it is likely that the vast majority of cases were decided according to the law, without any outside interference. But this was not the impression of ordinary citizens. They saw the ability of the regime to ignore the law and to dictate outcomes and did not want to open themselves up to this possibility. Hence, law was seen more as a weapon that the regime could use against them rather than as a weapon in their own arsenal. The idea that citizens could use the law to protect themselves against the arbitrary or illegal actions by the state was laughable.

Over the past two decades, as part of the transition from state socialism to some form of market democracy, virtually every facet of the legal system has been reformed, from the legislative base to the institutional infrastructure (Hendley 2006). Though the reforms were trumpeted as part of an effort to build a "rule-of-law based state" (pravovoe gosudarstvo), many Russians remain skeptical about the ability of this particular leopard to change its spots. It surprised few when, notwithstanding their lofty rhetoric, both the Yeltsin and Putin regimes proved themselves willing to revert to Soviet-style behavior by using the courts as a cudgel to punish political enemies and ignoring the letter of the law whenever convenient. ${ }^{6}$ Russians responded in kind. In a national survey fielded in the fall of 2007, 68 percent agreed that it was not possible to live in Russia without breaking the law. President Medvedev has railed against this so-called "legal nihilism," committing himself to further reforms of the judicial system and to reducing corruption in the courts and elsewhere. ${ }^{7}$

Most social scientists have taken this antipathy toward law and the legal system as conclusive evidence that Russians will not mobilize the law on their own behalf unless there is no other alternative (e.g., Hale 2005; Varese 2001; Hay and Shleifer 1998). I am less convinced. To be sure, their lack of confidence in the formal legal system - whether motivated by fears of political interference, corruption, or garden-variety incompetence - influences their behavior. But this assumption that contempt for the formal legal system translates into an unwillingness to invoke law in any form is too simplistic. ${ }^{8}$ The dualism of the Soviet legal system, in which

${ }^{6}$ In a survey fielded by the Levada Center in March 2007, 40 percent of Russians surveyed indicated that they believed that the state had dictated the outcome in the trial of the oligarch, Mikhail Khodorkovskii. But only 18 percent felt badly about this (http://www.levada.ru/press/2007030602.html, accessed on August 28, 2008).

${ }^{7}$ The speech given by Medvedev on January 22, 2008, available on the website of United Russia (http://www.edinros.ru/news.html?id=126928, accessed on August 28, 2008), is a good example.

${ }^{8}$ The official caseload data, which show a steady increase in almost all categories of cases (other than criminal), also belies this common wisdom (Hendley 2006). 
mundane cases are generally resolved according to the written law while political cases are resolved by "telephone" law, has carried over to the present-day Russian legal system (Hendley forthcoming). Few problems encountered by ordinary Russians are of interest to the Kremlin and so they may be willing to try using law. Along similar lines, it may be that attitudes are not always determinative when material interests are at stake.

In my work on Russian business disputes, I found that enterprises would resort to the courts to collect debts, notwithstanding their skepticism as to the capacity of these courts to provide justice (Hendley 2004). This disconnect between attitudes and behavior may carry over to non-business settings. Even if some are categorically opposed to going to court, this does not mean that they do not invoke law in some form. There are a myriad of strategies for resolving disputes short of litigation that bring the law into play. As has been well-documented, even in countries like the U.S. that are seen as being highly litigious, relatively few disputes end up in court (Trubek et al. 1977). Nowhere is litigation the optimal method of resolving problems. But the disputing literature generally assumes that it is a viable option and that the desire to avoid the expense and time required to litigate shapes the parties' behavior. To what extent this assumption holds in a country like Russia where threats to go to court may be perceived as empty remains to be seen.

\section{Methodology}

Studying the evolution of disputes is tricky. In a perfect world, the researcher would be an unobtrusive presence in the lives of potential disputants and could observe and document the original injury and the subsequent choices as to whether to pursue some sort of remedy. In reality, however, this is not feasible. Few researchers have the luxury to hang around waiting for injurious events in the lives of others. Moreover, their very presence would likely influence the decisions by those involved as to how to proceed. A more realistic strategy is to investigate disputes after they have run their course. ${ }^{9}$ This still requires the researcher to identify situations where disputes might have arisen and study how different people reacted to similar stimuli.

Home repair projects provide a setting in which problems often arise between home owners and those hired to carry out the work. During the Soviet era, the ability to carry out such projects was severely limited and typically required residents to work through the grey or "second" economy to locate building materials and workmen. Most struggled to carry out even essential repairs. With the break-up of the Soviet Union came the transition to the market and the lessening of shortages. This, combined with the ability to privatize their residential space and the revival of the economy under Putin, gave Russians a powerful incentive to improve their living space. In recent years, a multitude of construction firms have sprung up and the sales of

\footnotetext{
${ }^{9}$ Asking the focus group participants to relate past experiences raises well-known dangers of distortions due to subsequent events (Felstiner, et al.: 650). Even so, it seems to be the best way to gather information.
} 
construction materials has become a thriving business. Much as in the West, this work does not always go smoothly.

The realm of home repair projects is appealing not just because it is a fruitful source of potential disputes, but also because these disputes can be resolved through many different mechanisms. Unlike divorces or land disputes, which are statutorily required to be resolved by the courts (or other state-sponsored agencies) in Russia, disputes related to home repairs may or may not proceed through the courts. My conversations with friends and colleagues in Russia before embarking on the project confirmed that many people simply abandoned or "lumped" their disputes and/or came to some sort of private accommodation with their contractor. This certainly fits with what we know about such disputes in the West. At the same time, I also learned of disagreements that had blossomed into prolonged litigation. Thus, going to court was an option, at least in theory. How open people were to using law to protect themselves was less clear and became one of my research questions.

Focusing my project on problems arising from home repairs has the advantage of providing variation in terms of a number of variables that might affect the transformation of disputes. The scope of the renovations varied widely. Would those who had undertaken structural repairs be more willing to press forward than those whose repairs were cosmetic? The home repair projects also offered considerable variation in terms of relational factors. Russians routinely rely on friends' recommendations to locate workers. Would a fear of jeopardizing these friendships leave them reticent in the face of problems?

In order to explore how Russians deal with problems arising from home repair projects, I convened a series of focus groups populated by those who had recently completed such projects. Focus groups are the best option for exploring a process, in that they allow the participants to speak at length about their experiences and do not assume that the researcher knows the full range of answers (as does a survey instrument with closed-end questions). This paper is based on six focus groups conducted during the summer of 2007 in Moscow and Saratov. ${ }^{10}$ Each focus group included 9 to 11 individuals; the basic characteristics of the groups are shown in Table 1. (See Table 2 for background information on the respondents who are referenced in the article.) To accommodate the work schedules of the participants, the discussions took place on weekday evenings and lasted about 2 hours. Participants were given a modest honorarium to compensate them for their time. It was felt that having an American lead the groups would be unsettling for many and, due to the prevailing anti-Americanism in Russia, could skew the discussion. Thus, the groups were moderated by Elena K. Zobina, a research fellow at the Institute of Sociology, who is experienced in leading focus groups. ${ }^{11}$

\footnotetext{
${ }^{10} \mathrm{~A}$ total of six focus groups were held in each city. Three focused on home repairs and three focused on personal injuries. This paper focuses only on the home repair groups.

${ }^{11}$ I worked with Polina Kozyreva and Mikhail Kosolapov of the Institute of Sociology in Moscow, which is part of the Russian Academy of Sciences, on the logistical side of the project. Since
} 
The selection of these two cities as starting points for the research was designed to provide a contrast. Moscow (population: 10.4 million) is the financial, governmental, and cultural center of Russia. ${ }^{12}$ Though not entirely typical of Russia, it remains a touchstone for all Russians. Saratov (population: 841,100) is situated on the Volga River and serves as the administrative center for the surrounding region (Saratov oblast'). During the Soviet era, its concentration of defense industry meant that it was closed to foreigners. These defense-related factories have since foundered, undermining the economic base. A comparison of the average monthly wage for the two cities in 2007 illustrates the difference. While the monthly mean wage for Muscovites was about 18,000 rubles (or \$703), Saratov residents had to settle for less than half of that (8164 rubles or \$319). ${ }^{13}$ The unemployment rate for Moscow (1.5 percent) was a fraction of that for Saratov oblast' (8.2 percent). Not surprisingly, investment in Moscow dwarfed that for Saratov oblast' ${ }^{14}$

In organizing the focus groups, the goal was to bring together a diverse set of Russians who shared the common experience of a recent home repair project. We sought variation in terms of age, gender, educational background, and work experience. Hypothesizing that whether one came of age in the Soviet Union or in post-Soviet Russia would significantly influence attitudes and behaviors vis-a-vis law, we divided the groups along generational lines. Those who grew up in the Soviet era were socialized to expect the state (often in the guise of the Communist Party) to provide for their needs, while their children and grandchildren have learned that they have to fend for themselves. The younger generations have no direct personal experience of the courts serving as an instrument for dampening dissent. As a result, they may be more open to the possibility that law can serve their interests. For example, when asked in a 2003 survey by INDEM whether they would be prepared to go to court over unfair treatment by a governmental official, the results split along generational lines. Almost 60 percent of those 18 to 23 years old

1992, they have coordinated the Russian Longitudinal Monitoring Survey (RLMS), a series of nationally representative surveys designed to monitor the effects of Russian reforms on the health and economic welfare of households and individuals in the Russia (http://www.cpc.unc.edu/rlms/). Thanks to this work, Kozyreva and Kosolapov have developed a strong network of social scientists throughout Russia. We worked with their colleagues in each of the focus group sites to organize the focus groups. These local contacts recruited the participants based on the agreed-upon criteria.

${ }^{12}$ These data for Moscow and Saratov reflects the situation in 2007 at the time of the focus groups.

${ }^{13}$ According to the Russian Central Bank, the nominal exchange rate for the US dollar against the ruble was 25.60 during July 2007

(http://www.cbr.ru/eng/statistics/credit_statistics/print.asp?file=ex_rate_ind_08_e.htm, accessed on June 23, 2009).

${ }^{14}$ During 2007, capital investment in Moscow was almost 556 million rubles, while Saratov oblast' received less than 13 million. These statistical data are available in Regiony Rossii (http://udbstat.eastview.com.ezproxy.library.wisc.edu/catalog/readbook.jsp?issue=710418, accessed on July 29, 2008). 
responded in the affirmative, while only 36 percent said they would not. By contrast, among those 50 to 59 years old, the results were a virtual mirror image, with only 38 percent expressing a willingness to appeal to court and almost 60 percent saying they would not consider it.

According to the research design, in each locale, one group was to be composed of those who had come of age during the Soviet period. Another group was to be composed of those who had no meaningful memories of the Soviet period, i.e., those who had been teenagers or younger during Gorbachev's perestroika. The third group was to be a mixture of these Soviet and postSoviet generations.

As Table 1 shows, these aspirations were not entirely realized. The Moscow groups met the primary criteria of dividing participants by age and had a good distribution by gender and job experience, but were skewed toward those with higher education. The economic dislocation of the 1990s led to many redundancies for middle management. As a result, many people with university degrees have found themselves in jobs unrelated to their educational skills. The Saratov groups were more problematic. Though those responsible for recruiting participants were given a full set of the selection criteria, they did not follow them as rigorously as had the Moscow recruiters. The older and mixed generational groups were noticeably younger than in Moscow. More specifically, the older group inexplicably included a 21-year old. If she had been excluded, the mean age would have been almost 40, which would have been more appropriate, though still significantly younger than the older Moscow group. More problematic was the gender division. Of the 38 participants in the Saratov home repair groups, only 2 were men. ${ }^{15}$ The situation was not ideal but, as will become apparent below, the unintentional over-sampling of women in Saratov provided valuable insights into potential gender-related explanations.

\section{The Evolution of Disputes Arising From Home Repair Projects}

\section{The Absence of Conflict}

Many of the focus group participants embarked on their home repair projects steeled for the worst. A comment by Vera, a 35-year old psychologist from Saratov, perfectly conveys this sentiment: "Any home repair project is a natural disaster" (liuboi remont - eto stikhiinoe

\footnotetext{
${ }^{15}$ I had some warning of this. When I arrived in Saratov, the local organizer told me that I should be aware that, in Saratov, men did not involve themselves in home repair projects and so those groups would be primarily female. There is some truth in this, but it was also a convenient excuse for her inability to find male participants. I was faced with a difficult choice of whether to insist on a more even gender distribution or to take what I could get. My experience of doing field research in Russia convinced me that the latter was the more prudent. I had no prior relationship with the Saratov organizer and feared that if I were too demanding, she might refuse to help me at all.
} 
bedstvie). ${ }^{16}$ But a few were pleasantly surprised. Of the 84 home repair projects discussed during the focus groups, 10 (12 percent) were completed to the satisfaction of the homeowner. No one in this group attributed their success to having protected themselves through law. Instead, trust emerged as a common theme. For the most part, this trust was highly personalized. When undertaking renovations, they sought out recommendations from friends ${ }^{17}$ or hired relatives. ${ }^{18}$

A minority view was that conflict-free projects were the result of careful preparation and supervision. Kamal, a 37-year old participant in the first Moscow group, raised hackles within his group when putting forward this position due to his barely concealed contempt for the other participants' inability to control their workers.

I didn't make any of the mistakes that the rest of you did. In the

first place, I ... didn't play any sort of games with the state [by entering into a contract]. In the second place, I sent my wife on a business trip for two weeks. ... I hired a guy for two weeks, wrote out what he was supposed to do. I told him that I would be back in two weeks ${ }^{19} \ldots$ to verify that he had completed the work. ...

He found the worker at a local labor market. They had no pre-existing relationship, nor did any of Kamal's friends vouch for the worker. They did not bother with a written contract; neither Kamal nor any of the other focus group participants saw his detailed "to do" list as constituting a contract. Kamal told the worker that if the work was not up to snuff, he would not be paid. Though not explicitly stated, it is likely that the worker was an illegal immigrant. In any event, Kamal saw himself as having the upper hand. Yet he did not retain the worker's passport (as many in Russia do when employing illegal immigrants), so the worker could have left anytime, albeit without being paid. When the other participants asked what Kamal would have done had

${ }^{16}$ Focus group participants were guaranteed anonymity. Their names have been changed. The focus groups were conducted in Russian. All translations are by the author.

${ }^{17}$ Homeowners acted on recommendations of friends or colleagues in two-thirds of projects discussed. The tendency to do so was higher in Saratov (75 percent) than in Moscow (59.2 percent), which reflects the greater degree of anonymity in a metropolis like Moscow as compared with a sleepier regional urban center like Saratov.

${ }^{18}$ For example, when Lilia's mother of decided to install a sauna at her home, Lilia worried that outsiders would take advantage of her mother. In her words, "everyone sees an elderly woman and assumes that they can do the minimum amount of work for the maximum money." They hired relatives and the work was completed "without conflict."

${ }^{19}$ Kamal remained in Moscow for these two weeks. Russians typically decamp from their apartments and stay with friends or relatives while renovations are underway, allowing the workers to live in their apartments while the work is completed. This practice is essential if non-local (especially non-Russian) workers are hired. Often workers are recruited from rural areas. Their wages tend to be lower than for those from urban environs, especially Moscow. 
the worker simply disappeared before completing the assigned tasks, perhaps absconding with the building materials (as happened to a number of them), he responded with a slang phrase [kuda on denetsia] that meant that he believed the worker had nowhere to go.

Though the participants who were satisfied with their home repair projects attempted to come up with reasons why, the true commonality among them was luck, because the factors that they identified as the key to their success were also cited by people whose projects failed. As will become apparent in the discussion below, many who had horrific experiences did their best to hire reputable workers, checking out their potential workers' references and seeking out prior employers to assess their skills. Indeed, many went far beyond Kamal and checked up on the work every day. Even so, they were disappointed. The fact that several of those who were completely satisfied with one home repair project were put through the wringer in other projects also supports the idea that chance plays a key role. The opinion expressed by Dmitrii, a 49-year old Muscovite, encapsulated the feelings of all the groups: "decent [poriadochnye] people are becoming more and more rare."

\section{Unperceived Injurious Experiences}

More interesting than these few participants who had good experiences are those who had problems, but did not view them as worth pursuing. Felstiner, et al., recognize that the same stimulus may be experienced differently, i.e., that the same event that is seen by one person as an injurious experience may be viewed as a minor inconvenience by someone else. They label such events as unperceived injurious experiences or un-PIE (pp. 634-635). There were surprisingly few of these among the focus group participants. Perhaps this is due to the fact that injuries in home repair projects manifest themselves with inescapable evidence, such as leaky roofs or peeling wallpaper, that cry out to be fixed. Though a few people still looked the other way when confronted by such evidence of injury, they were the exceptions. This makes home repair projects different from more intangible injuries, such as bruised feelings, that may be perceived as more or less serious, depending on the world view of those involved.

The only un-PIE were among the Saratov participants. In each of the three Saratov focus groups, there was a woman who, despite expressing some dissatisfaction, did not regard the experience as injurious. Like many of their counterparts, these women's projects had experienced cost overruns and had taken longer than originally planned. Unlike their counterparts, these women chose to turn the other cheek. Two of them, Sara and Diana, did so because their satisfaction with the quality of the work, once completed, outweighed their annoyance at the failure of their workers to live up to their promises on cost and timing. For 
example, after putting a huge effort into finding just the right brigade ${ }^{20}$ to do her repairs ${ }^{21}$ Sara's workers (in her words): "were not entirely able to confine themselves to the deadline and cost estimate. ... For ourselves, we decided that a 20 percent cost overrun - this was normal. And the deadline didn't bother us much. ... We weren't in a hurry." Her composure in the face of delay was driven largely by the fact that she and her family were living cost-free with friends during the renovations.

The third Saratov participant who fits into the un-PIE category, Liubov, was faced with an analogous situation. The renovation of her apartment ended up taking twice as long as promised and costing 30 percent more than the estimate. During the construction, she and her family had moved in with her parents to give the workers free access to the apartment. Though she reacted with less equanimity than Sara, admitting to the group that the delay was extraordinarily inconvenient as were the additional charges, she stopped short of labeling her experience as injurious. In her words: "we simply sat and waited. ... We had no complaints against them because they came to us from our friends." Her restraint was driven by her desire not to damage her relationship with the friends who had recommended these workers. Her fatalistic attitude surfaced as she remarked: "as with anything Russian, everything turned out the opposite of what was intended."

These two examples provide a perfect illustration of the way in which similar experiences can be perceived differently. Both Sara and Liubov had to pay more than they anticipated and both of them had moved out of their apartments during the renovations. For Sara, living elsewhere was an adventure and she was not troubled when the project took longer and was more expensive than originally planned. Liubov, by contrast, clearly felt that she and her family had outstayed their welcome with her parents. Her reluctance to jeopardize her friendship with the friends who had recommended the workers not only prevented her from voicing her disappointment to the workers, but also kept her from acknowledging the injurious nature of the experience to herself.

\section{Naming}

These few examples of satisfaction or satisficing were the exception. Most of the focus

\footnotetext{
${ }^{20}$ Brigades are groups of workers who hire themselves out as groups. The homeowner would typically deal only with the brigade leader and would then trust him or her to assemble a competent crew. There is no licensing process for brigades.

${ }^{21}$ Sara put much more effort into organizing her renovations than did Kamal. She explained: "I spent rather a lot of time. I even organized a competition. I asked them to sketch something and to write up an estimate. It was possible to grasp the extent of their professionalism by their conversation. We settled on the second brigade because they were very rational and were a family. Also, they had done some work for my aunt..." Once the work was underway, "we verified every step..." As I noted earlier, this suggests that, rather than having the key to success in home repair projects, Kamal was simply lucky.
} 
group participants acknowledged their experiences with home repairs as injurious. Of the 84 projects discussed during the course of the focus groups, this sort of naming of the injury occurred in 71 (85 percent) (see Table 3). Felstiner, et. al., characterize this shift from unPIE to PIE as "the critical transformation," noting that "the level and kind of disputing in a society may turn more on what is initially perceived as an injury than on any later decision" (p. 635). Because naming is an internal process that turns on individual level perceptions, it can be difficult to document. The focus group methodology encouraged participants to share their thoughts. Their anonymity from each other freed them to speak openly.

Like homeowners elsewhere, Russians are annoyed when renovations do not proceed as expected. Time delays and cost overruns were part of the story in about a third of the named injuries. Few were as tolerant as the three Saratov women described above. Most saw the inconvenience and added expenses as injurious. Delays can try the patience of the homeowners and their temporary hosts, especially when children are involved.

Even more common were claims of substandard work and, more specifically, the lack of professionalism of the workers. Quality complaints were present in 61 of the 71 cases (86 percent) in which the injury was "named." The glaring nature of many of the quality issues (such as holes in the floor or peeling wallpaper) made their recognition as injurious unsurprising. What constituted unprofessional behavior is a dicier question. Complicating matters is the tendency to hire immigrants from other parts of the former Soviet Union because they cost less than Russian laborers. This is especially common in Moscow. ${ }^{22}$ Untangling the legitimate criticisms from preexisting prejudices proved impossible. This is not to imply that Russian workers were necessarily better. A comment by Valentina, a 43-year old manager of a Moscow children's theater, summed things up well: "Of course, it is more pleasant to interact with Russians, rather than Moldovans or Tadzhiks, but Muscovites are all alcoholics." Typically the lack of professionalism gave rise to substandard work. On its own, i.e., where occasionally drunken workers did quality work, it did not serve as a basis for naming.

Naming was a fairly straightforward exercise for the focus group participants. Few denied the obvious fact that work that was inferior, late, or unexpectedly expensive was injurious. With the notable exception of Liubov, no one allowed relational concerns to inhibit them.

\section{Blaming}

Assigning blame to a third part for an injurious experience transforms it into a grievance.

\footnotetext{
${ }^{22}$ Most of the immigrants who seek out construction work are in Russia illegally, which helps explain their willingness to work for less. The pluses and minuses of hiring them was a theme in all of the Moscow focus groups. This practice is, of course, illegal, but only one of the Moscow participants (Dmitrii) identified this as a constraint, noting: "hiring non-citizens doesn't make sense because you risk having to pay a fine of about 200,000 rubles [approximately $\$ 7813$ ]."
} 
Within the Felstiner-Sarat-Abel framework, blaming (like naming) is a process that is internal to the injured party. It is a recognition of who is responsible for the injury that has been named, but does not requires the injured party to confront the wrongdoer. That comes with claiming. Thus, like naming, blaming is a low-cost activity, though it can take a toll emotionally. In contrast to settings where responsibility for poor outcomes may be diffuse, assessing fault is not difficult for most home repair projects. As the various tales of woe were related, the villains were inevitably those who had done (or, in some cases, failed to do) the work. Though there were varying levels of anger, the primary locus of blame was clear. For most of the focus group members, blaming was collapsed into naming.

A careful analysis of the discussion in the focus groups reveals a recurrent theme of selfblame. For a few, their own guilt preventing them from blaming anyone else. ${ }^{23}$ For example, Inessa, a 45-year old schoolteacher from Saratov, found two women, who had been recommended to her by friends, ${ }^{24}$ to renovate her one-bedroom apartment. She stayed at home while the project was underway and believed that her efforts to make these workers feel comfortable by feeding them ${ }^{25}$ and gossiping with them had somehow backfired. They were a bit older than her and she described them as "very amiable." Yet she also found that the "more they talked, the less they tried [to complete the work]." After they left, she found that some of their work had been slipshod, but felt that she could not blame them because she had approved the work at the time.

The more common pattern was to shift some, but not all, of the blame onto oneself when a person felt that his or her own actions had contributed to the injurious nature of their home repair projects. Among this subset of the participants, some berated themselves for not paying more attention to the work as it was proceeding, echoing an issue raised by Kamal's diatribe above. Mark, a 47-year old Muscovite, had bought an apartment for his adult son and had hired a Ukrainian brigade to renovate it. Among other things, the project called for new wallpaper throughout the apartment and new tile in the bathroom. As a fashion designer himself, Mark had strong feelings about the esthetics of the space. He was deeply disappointed by the work, commenting: "I don't know what they did with the construction materials [that I bought for the project]. The biggest mistake was mine. I failed to keep them under my control. I work day and

${ }^{23}$ Felstiner, et al. (p. 641), predict that self-blame will color the perception of the incident, making it less likely to be seen as injurious. This was not born out by the focus group participants. Though they were unwilling to blame, they had named their injuries.

${ }^{24}$ Inessa was adamant about not hiring men, noting that "too often our men are alcoholics and tend to disappear from work ..."

${ }^{25}$ The question of whether feeding the workers was a good idea became a bone of contention in many of the groups. Some felt that it would have been rude not to provide lunch. Others believed that serving lunch created an unhealthy sense of familiarity between the workers and the clients that then made it difficult to point out shortcomings in the work. Alla, a Moscow pensioner, said that she might recommend the young man who had worked for her to others, but would caution them not to feed him. 
night. Over the two weeks [of the project], I was in the apartment maybe two or three times."26 Yet he still saw the project as an injurious experience and, notwithstanding the hyperbole of his comment to the group, put primary blame on the workers and demanded that they redo their work.

This propensity for self-blame came through even more potently in the Saratov groups. Because they were dominated by women, it is tempting to cast their responses as gender driven, especially given that the respondents themselves often framed their behavior in terms of gender. Nadia illustrates this nicely. She is a 20 -year old Saratov university student who still lives with her mother. They decided to install a washing machine and needed some plumbing upgrades. Her mother consulted with friends and found a brigade of three men and they agreed on the price and deadline for the work. For them, the fact that these workers were Christian family men was just as important as the price for the work. At the outset of the project, they had a good relationship with the workers, even giving them a key to their apartment and fixing their meals. The project seemed to be going smoothly. Over time, however, Nadia's boyfriend grew suspicious of the amount of money the women were spending on the project and started investigating. Explaining why the women themselves failed to notice a problem, she said: "we, as women, didn't understand anything about what the workers were saying. We believed what they told us. However much they said it was going to cost, that's how much it would be." According to the boyfriend, the amount they had given the workers was sufficient for "a Kremlin hall." It turned out that the workers had been buying more material than was needed and had been using these excess materials for other construction projects. Though she described herself and her mother as "non-conflictual" (a common theme among the women of Saratov), they were willing to name the injury and to place blame on the workers.

Of the remaining handful that did not engage in "blaming," the reasons varied. Daria from Saratov, who was already a pensioner at 55, said that when the newly installed bathroom tiles began to pull apart from one another after only a month, "I wasn't sure who was at fault." Several others felt that pursuing things - whether by blaming or claiming - would have been more trouble than it was worth. When the wallpaper started to peel off only 18 months after it had been put up, Elena simply bought some super glue and fixed the problem herself. Several others expressed a sense of resignation tinged with a desire to spend their time more productively. Another woman from this same Moscow focus group, Lidia, said that she "didn't feel like cursing and threatening every time [something went wrong]." Doing so took emotional energy that she preferred to devote to her family. This theme, which taps into the legendary Russian capacity for suffering, will become even more pronounced as we turn to claiming.

\section{Claiming}

\footnotetext{
${ }^{26}$ As an aside, it is worth noting that Mark visited the work site more often than Kamal, who felt laying out the ground rules and then staying away was part of the secret to his success. These two men participated in two different focus groups so there was no exchange between them.
} 
The first two stages in the Felstiner-Abel-Sarat framework do not require any sort of affirmative action, but endeavor to capture the evolution in the injured party's thought process. With claiming, however, the grievance becomes apparent to the outside world. The injured party notifies the person or firm responsible and asks for some sort of remedy. If it is rejected, then it becomes a dispute (Felstiner, et. al., p. 636). The type of redress sought can take a wide variety of forms, ranging from apologies to restitution to full-fledged litigation. In fact, analogous situations can give rise to radically different claims, illustrating the potent role played by the perceptions of the injured party in shaping the demands made. If an injury is seen as serious, either due to the amount of money or principle at stake, then the injured party is unlikely to settle for an apology or some other face-saving gesture that might be sufficient for a more minor injury. Thus, just as with the earlier stages of naming and blaming, context matters.

Explaining the Failure to Claim. Felstiner, et al., theorize that not all injurious experiences give rise to claims. My findings bear this out. Almost half (43 percent) of those who were disappointed with their home repair projects did not make any sort of claim. A full third of those who felt someone else was to blame did not seek any remedy. What sorts of factors account for this willingness to "lump" their injuries? Felstiner, et al., argue that a recognition that the cost of pursuing the problem, whether measured in time, emotional energy, money, or relational damage, outweighs the potential benefit will cause abandonment. They also note the potent role of law as a transformational agent, e.g., if the law does not support the claim, then it is less likely to be pursued. The behavior of the focus group participants is generally consistent with these general assertions, albeit with a Russian twist.

Being Russians, there was a cloud of gloom and doom that hung over the discussion. Medvedev has framed this in terms of legal nihilism, but it goes deeper. This sense of fatalism was expressed by Flora, a 36-year old teacher, who had hired two different brigades to renovate the apartment she bought when she moved to Saratov, both of whom had proven unreliable and incompetent. She did not make any effort to seek recourse from them. Instead, she and her husband redid the work themselves. She told the group: "I am sorry for our country. I wish things were better here - that people weren't lied to all the time. We all just want to live." Her cost-benefit analysis goes to the very heart of the Russian character.

Others were more prosaic. There were several respondents who simply did not want to be bothered any further. Sometimes this was because the repairs had been relatively trivial and so any amount recovered would likewise be trivial and not worth the effort. ${ }^{27}$ Sometimes it was because the respondents were unwilling to expend the necessary emotional energy. Typical was

\footnotetext{
${ }^{27}$ In Saratov, for example, many participants had replaced their windows. In the Soviet era, window frames were wooden and prone to leaks. During the winter months, most people had to glue newspaper strips to avoid drafts. A thriving business in replacing these old windows has grown up in recent years. Some firms are more competent and reputable than others. Those who deal with the less able firms often come away dissatisfied. Yet the amount paid is not large enough to cause most severe financial discomfort. Hence, they tend to walk away.
} 
Sofia, a 49-year old Moscow engineer who, when asked why she opted to make no claim when a renovation of her apartment that cost over $\$ 10,000$ went wrong, responded: "I decided to spare my nerves." In other cases, the respondents did not want any further contact with the workers, even if it might have resulted in getting the work redone or some monetary recovery. A good example is Polina, a 32-year old manager of a Moscow travel agency, who hired two Ukrainian women to even out the ceilings in her apartment and to put up new wallpaper. ${ }^{28}$ As the project evolved, she figured out that the women were not as experienced in home repairs as they had claimed to be. They did not tell her that the door in the kitchen ought to be hung before the wallpaper was put up, which caused delays and extra expenses. Yet she made no claim against them, though the terms of her contract guaranteed the quality of the work, primarily because making a claim would have inconvenienced her in that she would have had to delay a longplanned vacation.

The bulk of those who failed to claim were stymied. They felt themselves entitled to some sort of restitution, but were blocked by circumstances. The two issues that came up most frequently were the inability to locate the party at fault and the lack of a written contract. Often the two were interlaced with a schizophrenic combination of fatalism and legal positivism. The propensity to hire brigades or individual workers - often immigrants - rather than established firms increased the risk that the workers would disappear into the wind when problems arose. But hiring a firm was no guarantee of stability. In Russia (as in many other countries), construction firms come and go quickly, leaving few traces. Often they have no actual office, but only someone who answers the phone and takes orders. When problems arise, the phone number is quickly changed. The focus group members, who frequently invoked the word "disgraceful" (bezobrazie) to describe the behavior of the workers and firms, believed that it went largely unpunished because those injured felt they had no recourse when they used these fly-by-night firms.

A pattern revealed itself among the Saratov participants. They would prepay for work and would then be unable to find anyone to take responsibility when the work was done in a slipshod manner. Nina hired a firm to do some plumbing work. In the course of the job, they created a hole in the floor of her bathroom, such that one could see through to the lower floor. When she confronted the workers, they shrugged and told her that's how it had turned out [tak poluchaetsia]. When she and her husband tried to call the firm itself, no one picked up the phone. Eventually she gave up and hired someone else to do the job. She never got the money back that she had paid the incompetent plumbers. Another woman from the same group, Antonia, prepaid to have her balcony enclosed with glass. When the workers came, only her elderly mother was home. They only framed out the job; they did not put in the glass. Like Nina she was never able to contact the firm. When asked whether it would make sense to search further for the workers or the firm, her answer was definitive: "it would be absolutely pointless." She too was out the money for the repair and, though she had named and blamed, was left unable to claim.

\footnotetext{
${ }^{28}$ Like Inessa, Polina was categorically opposed to hiring men to work in her home.
} 
Underlying their frustrations was a belief that the law would not be receptive to their claims. Neither of these women had signed a contract. Among the focus group participants, it was taken as an article of faith that recovery through the formal legal system required a formal written contract. Thus, even if they had no intention of initiating litigation, many felt seeking any sort of remedy was futile if they lacked such a document. Yet they rarely demanded a contract at the outset because they felt uncomfortable doing so. As Valentina explained: "Probably we are too trusting. We assume that nothing will go wrong." She had electrical work done at her Moscow apartment and was displeased by the results. Unlike the Saratov women, she had worked through an established firm and was able to contact them. They gave her the cold shoulder, telling her: "unless you have a contract in hand, we won't talk to you. We never concluded a contract with you. Take your questions to court." Not surprisingly, she dropped it. In another Moscow group, a younger woman, Tamara, explained why her hands were tied when the ceiling tiles started dropping off a month after being glued into place: "We hired a brigade, but we didn't have a contract with them. It was useless to call them. They had vanished. We had only their cell phone numbers. They were not Russian citizens. As a result, we had to have the work done a second time." She was fortunate that her uncle was able to redo the work at no cost. But even if she had been able to locate these workers, she was convinced that the absence of a contract left her with no viable claim against them.

At first glance, what I am describing would seem to be a lovely illustration of how both the injured parties and those to blame are operating in the shadow of the law. Though litigation is not yet on the table, both sides are taking account of the likely outcome of litigation in fashioning their bargaining strategies. If the firm that did Valentina's electrical work thought it could be held liable by a court, then it would probably have settled with her. Its high-handed behavior only makes sense when we factor in its belief that the lack of a written contract places it beyond the reach of the law. Likewise the apparent diffidence of Tamara and others becomes more logical when we factor in her rock-solid belief that she could not insist on any remedy without a contract. What makes this particularly fascinating is the fact that they are all wrong. Much like Ellickson's Shasta County ranchers (1991), these Russians' version of the law is distorted. In the older Moscow group, this came to the fore because one of the participants, Ivan, was a frequent litigant and had educated himself on the details of the law.

Ivan: You don't need a contract. Pay attention here - a receipt is good enough because it confirms that you paid for the work. If I pay you 100 rubles, that means that I consider that to be the value of the work you did. If you disagree, that's fine, I'll go to court. I guarantee you - if you write up a complaint and ask that the court order your construction firm to redo the work, your construction workers will show up and do the work.

Moderator: So this works if you threaten them?

Ivan: It's not a threat - it won't be taken that way. I guarantee that the firm will fly to you....

Marina: Our people [Russians] don't know these legal details. As a general rule, our people are not legally literate. ... We believe what we are told. ... We want to 
believe in other people's humanity. Plus we don't have time [to investigate the law]....

Ivan: If you have an agreement [dogovorennost'] - if everything is settled, and then something is done inappropriately, then write up a complaint. That firm will ruin itself over you.

Marina: This is all rubbish.

Ivan: Here's what I have in mind - people in Russia are not accustomed to

fighting for their rights even a little bit. Right from the start, we say - that's okay

- it's only a few kopecks - it doesn't make sense to pursue. ...

Alla: What do you mean by fighting? I don't like this. We shouldn't have to fight for something that we already paid good money for.

A review of Russian contract law confirms that Ivan is right. Oral contracts are enforceable under Russian law if there is documentary evidence to support them. As he suggests, the best evidence would be some sort of signed receipt, indicating that work was completed. No construction job is ever considered complete in Russia until an "act" (receipt) is signed acknowledging it. Thus, it is likely that all of the focus group participants who believed that they were unable to make claims because they lacked a written contract were, in fact, entitled to claim. What is more fascinating is how the construction firms use this misapprehension to their advantage. I did not have an opportunity to speak with representatives of the firm in question. It is possible that they were not taking advantage; it is possible that they were just as misinformed as their clients. The hostile reaction of the other focus group members to Ivan's explanation of how the law really works demonstrates how deeply held this belief in the magical power of written contracts is. In the other groups, no one challenged the conventional wisdom.

Felstiner, et al., emphasize the potential for relational damage when hypothesizing as to why so many disputes never proceed to the claiming stage. But among the focus group participants who did not claim, few cited relational concerns. Those who did were not worried about preserving their relationships with firms or workers. Nor was there any broader concern about being perceived by others as a trouble-maker. This is understandable in Moscow, where its size makes residents largely anonymous. Saratov also proved large enough to forestall this concern. $^{29}$ To the extent a fear of relational damage was relevant, the relationship at issue was with whoever had originally recommended the workers or firm. Although almost every focus group participant had gone through their friends to locate workers, only a few people cited a fear of undermining these friendships as a reason for not claiming. ${ }^{30}$ More often, people said that

${ }^{29}$ Fears of being seen as a troublemaker loomed larger in the focus groups I conducted in two small towns (Shumerlya and Kushevka) during the summer of 2008. Young people, in particular, were concerned about getting such a reputation, fearing that it would make it impossible for them to get a job.

${ }^{30} \mathrm{~A}$ good example is Feliks, a 43-year old Moscow real estate agent, who found workers through a friend. He was dissatisfied with their work, naming the experience as injurious and blaming the workers. But he did not claim because he did not want to risk angering the friend who had made the 
revealing that the job had gone badly and/or pushing the workers to redo the work would not negatively impact their relationship with the recommender.

Variants of Claiming. As Table 3 shows, a full two-thirds of the focus group participants who had blamed, also claimed. At this stage, a critical regional variation emerges. While 68 percent of the Moscow blamers were claimers, this figure was only 54 percent for Saratov residents. Claiming took one of two forms in this Russian context. Either they sought some sort of remedy from the workers or firm or they pursued an administrative complaint. Only two claims - both of which began as administrative complaints in Moscow - blossomed into lawsuits.

Claiming by Seeking Redress from Contractors. The focus group participants who sought recourse from those who had done the work often initiated their claim with a request that the mistakes be corrected. Lively debates erupted in all of the groups over the relative difficulties of seeking redress from established firms, brigades, and individual workers. Everyone seemed to feel that whatever option they had not taken would have been more fruitful. As discussed earlier, locating individual workers or brigades once work has been completed can be difficult. Those who had been burned in this way resolved to work through an established firm the next time around, even if this cost them more money. They reasoned that such firms were less likely to disappear and were more likely to use written contracts which the focus group participants believed would increase their options if problems arose. Those who had suffered through bad experiences with established firms provided a useful corrective. ${ }^{31}$ Most conversations concluded that much depended on the integrity of the people involved, whether at a firm or not.

The reality is that there were no guarantors of success. The experiences of the focus group participants show that when a claim is made by contacting those who had done the work whether an established firm, a brigade, or an individual worker - some effort was usually made to fix the problems. Sadly, the job was rarely done satisfactorily the second time around. Some then dropped their claim and redid the work themselves, reasoning that haranguing the workers

recommendation. Also relevant to his decision was the fact that he had no contract with the workers. A more extreme example is Roman, a 31-year old Moscow computer programmer, who found workers through the friend of a friend. He had only an oral contract. The renovation of his bathroom was done while he was away for 3 months. He returned to a flooded bathroom. Like Feliks, he was prepared to name and blame, but stopped short of claiming. He explained that he had no interest in fighting and that he did not want to embarrass his friend. He even took some of the blame on himself because he had not been present during the work.

${ }^{31}$ Evgeniia, a 31-year old Moscow manager, had very different experiences when dealing with established firms. When she called the firm she hired to put in a metal door to report that the installers had left a significant gap between the door and the floor, the firm refused to send workers to fix the problem. She came up with a makeshift solution herself. On the other hand, when the lock on the door failed after three years, that firm honored its guarantee and repaired the lock promptly. 
was not worth the trouble. ${ }^{32}$ Others demanded some form of restitution, either in the form of a lower price for the job or reimbursement from the workers. Margarita, a 50-year old Moscow library worker, wanted to "punish" the Tadzhik brigade who had misled her as to their construction skills, but settled for making them redo the repair work on her windows and got them to pay for a window that they broke. She blamed herself for the situation because she had stuck with them even when it became apparent that "they were not professionals." She did so on the grounds that other workers might be even worse. This sort of self-help remedy was fairly common, though not always accompanied by self-flagellation. As I noted earlier, women were more likely to blame themselves. Margarita was divorced, so handled the workers on her own. By contrast, when the brigade hired by Daria to enlarge the front hall of her Saratov apartment mistakenly knocked down a wall, she called her husband home from work. He ordered them to fix the problem and, when he was dissatisfied with their efforts, he fired them and refused to pay them the full amount agreed upon. His status as an active military officer probably affected the workers' willingness to go away quietly. Daria described her husband as "stern" and said that he "would not pay them for doing nothing." Her husband then took over the project and hired new workers and supervised them closely and the project was completed to their satisfaction.

Somewhat surprisingly given the ubiquitousness of relying on friends to find contractors, the fear of relational repercussions rarely affected the willingness to claim. For example, Zoya hired a family friend to do her repairs, but did not shy away from sharing her disappointment in his work. She noted, "it seemed to me that he delighted in creating chaos in my home. ... He was happy about all the dirt. ... We paid him less - a great deal less - than he asked for." When others asked her opinion about him, she responded, "Oleg is capable, but I cannot recommend him." Larisa was in a more awkward position. She and her mother undertook a major renovation at their three-room Saratov apartment, replacing the wallpaper and evening out the ceiling. The work cost substantially more than originally contemplated and took six months, which was much longer than they anticipated. More importantly, they were disappointed in the quality of the work. They asked that some of the work be redone but, when it was still subpar, they did not press further. Larisa explained that she worked as a bookkeeper for the wife of the brigade leader and so was uncomfortable doing more. Thus, a pre-existing relationship occasionally did dampen complaints.

Claims are not necessarily static. As Felstiner, et al, remind us: "The grievant's choice of an audience to whom to voice a complaint and the disputant's choice of an institution to which to

\footnotetext{
${ }^{32}$ Mark's disappointment with the work of the Ukrainian brigade he hired has been detailed earlier in the discussion of blaming. When he demanded that they return to retile the bathroom to his satisfaction, they returned for awhile, but did not complete the work. They disappeared into the wind. He chastised himself for not including their passport information in the contract, which would have allowed him to locate the workers. Katya, a 38-year old housewife who participated in another Moscow focus group, gave up in frustration when the repair of the repairs fell short, saying "I tried to fix the problems only with my own hands. I took care of things. After all, who could I complain to?" She had not hired a firm, but several individual workers by their specialties.
} 
take a controversy are primarily functions of the person's objectives and will change as objectives change" (1980-81: 642). For the focus group participants, litigation might be a logical next step after bilateral negotiations failed. Of those who claimed initiated claims with their contractors, only three - one Saratov and two Moscow participants - invoked the possibility of formal legal action. The two Moscow respondents threatened the possibility of litigation with mixed results when they were dissatisfied with the responses of the firms to their complaints. Karina, a 31-year old doctor, located a firm via the internet to install an air conditioner in her apartment. She had trouble with the workers from the moment they showed up. They "rebelled" when she insisted that they complete the work in a single day, as the contract provided. Though they grumbled, they did the work. They refused to test the units or to clean up after themselves. After they left, she discovered that one of the units did not work and that they had left a hole in the wall. She called immediately, but got the run around. When they sent a repairman, he proved unable to get the unit working. She then revised her demand. Arguing that the unit had never worked properly, she asked for a replacement. Again, the firm dithered, accusing her of having somehow damaged the unit. Things dragged on for over a month. As she said, "as long as I was unwilling to threaten court action, the air conditioner was not going to be replaced." Once she upped the ante, the firm replaced the unit. Such threats only work, however, when they are perceived as credible. Elena, the other Moscow respondent who threatened litigation when a large-scale renovation of her apartment went off the rails, taking twice as long as anticipated and costing three times more than originally planned, did not seem to take her own threat seriously. In response to a question from the moderator, she said: "we threatened to go to court, but who is frightened by that nowadays?" Instead, she felt that only when she and her husband started to ride herd on the project more closely did the workers settle down. Neither of these Moscow respondents consulted with lawyers before making their threats.

Indeed, the very idea of seeking help from lawyers was a non-starter for the focus group participants. Whenever the moderator brought it up, she was quickly shouted down. Almost none of the focus group participants had had any personal experience with lawyers and, while they raised familiar concerns about the cost and competence of lawyers, the tone of the discussion made it clear that they simply did not see how lawyers could have been helpful to them. The only exception was Viktor, a 33-year old Saratov doctor, who ran into trouble during the construction of his summer house (dacha). The workers used inferior bricks, which made the house harder to heat. Victor used a lawyer to make his claim against the construction company. The lawyer threatened litigation and then negotiated a settlement by which the construction firm agreed to pay for the higher cost of the heating unit. We should not read too much into this exception. Viktor's lawyer was a school-mate, whose services were free. The generalized hostility to lawyers among the focus group participants suggests that lawyers are less important as transformational agents in Russia than in the US (cf. Felstiner, et al.: 645).

Claiming Through Administrative Complaints. A second route to claiming is through an administrative complaint. Such complaints are appropriate when repairs have been undertaken (or should have been undertaken) by the state (or a quasi-state agency), in the form of the housing commissions. They have various names, but are typically referred to as the ZhKU (Zhilishchno- 
Kommunal'nye Uslugi or Housing-Communal Services). These commissions are a vestige of the Soviet past when almost all housing was owned by the state. Although much of the Russian housing stock has now been privatized, these $Z h K U$ persist. They are expected to maintain the buildings and to ensure a steady supply of energy and water. They are viewed as remote and uninterested in residents' problems.

There was an interesting discussion in the Saratov older group as to whether complaining to the $Z h K U$ is worthwhile. Liudmila, a 40-year old museum worker, told the group what happened when she lost hot water supply in late December 2005. She called her ZhKU to complain, but was put off until after the Russian Orthodox Christmas, which falls on January $8^{\text {th }}$. She told the group, "The plumbers from $Z h K U$ only feed us with promises. When you call, there is some old woman [babushka] who sits there and tells everyone that all the workers are out on a call; just wait. ... I was in a panic; I was crying." When the moderator asked her whether she thought about complaining further, it provoked the following exchange:

Liudmila: What? Complain to the chairman of the ZhKU? I don't know whether this would have resolved the problem. ... One time in the past I had a skirmish with her. And nothing happened. I decided to spare my nerves. We had a situation where the faucet was stopped up and we had no water at all. I then went to see her three times, ... but she did nothing.

Moderator: Did the other residents also have no water?

Liudmila: Yes. Each of them resolved the problem in their own way. Some of them also went to see the chairman. Maybe the problem was resolved because our neighbor on the fifth floor is maybe a procurator [prosecutor] or a lawyer and her boss called and bitched them out.

Anna: For me, not having water - this is a tragedy. Maybe I could survive without gas or electricity - whatever - but not water. I would definitely bug the chairman. Why wasn't there any warning - why wasn't there an announcement! And them I'd expect a personal call from the chairman: "Annochka, you'll have water in two days."

Liudmila: It's not clear what method would be most realistic in this situation. Probably, no one sues these organizations [ZhKU]. It's useless.

Maria: We've become accustomed to solving problems as they arise. We had a very similar situation - also before New Year's - the local TV station even came. We have only partial utilities - only cold water. Water started leaking, though not streaming. We called $Z h K U$. No one came. Everyone was out on a call. The next day, once again everyone was out on a call. We called the emergency services. They came at $2 \mathrm{am}$. We have small children. They were drunk and started singing. Then they asked us to make them some tea. What did they do? They broke the pipe and temporarily plugged it with a piece of wood; then they told us to call our own repair service. We waited about a week. We then got in touch with the local television station. Our situation was shown on TV.... After that, the workmen showed up and installed a new pipe and two faucets, all at no 
charge. But we still gave them a bottle of vodka out of gratitude. [She then went on to share another problem with the chimney of her building and her frustration with the $Z h K U$.]

Sara: Did you think about suing the $Z h K U$ ?

Maria: I am a single mother ... I have no money for going to court. I can't prove anything to anyone. The chairman [of the $Z h K U$ ] has office hours once a week for two hours. I'd have to hang around and wait for him. He's a young guy - much younger than me. ... I've come to the conclusion that the leadership of Saratov has decided that the dregs of society live in communal apartments. ${ }^{33}$ But I'm simply divorced from my husband. It's not necessarily true that bad people live there we're not bad people. ... No one pays attention to us.

The frustration with the $Z h K U$ is palpable. Neither of these women who sought help from the $Z h K U$ received it in a timely way. Neither viewed litigation as a viable alternative. Both worked through informal channels to solve their problems when the $Z h K U$ turned a deaf ear. Liudmila managed to find a friend to fix her problem. Had she not called on her friend, she would have waited for the $Z h K U$ workers or perhaps might have hired a third party. It would never have occurred to her to take the problem to the media, as did Maria, though they were about the same age. The media was able to shame the $Z h K U$ into living up to its obligations. In another incident related by Maria, she went to see her local deputy to complain about the poor condition of the roof when the $Z h K U$ kept postponing needed repairs. The others in the group were clearly surprised by Maria's persistence and activism. At first glance, she did not seem like the type to go down this road. As she herself noted, she is a single-mother. She has a high-school education and was working as a hairdresser at the time of the focus group. She had some experience with the courts as a result of her divorce, which was quite contentious. Her inventiveness in claiming seemed to stem from her belief that she had nothing to lose and no one to rely on but herself. Litigation was a not a viable option for her, not only because she did not have enough money to hire a lawyer, but also because her prior experience in the courts had undermined her trust in the institution.

From a legalistic perspective, claiming culminates in a lawsuit. As the foregoing indicates, in Russia, as elsewhere, most injurious experiences are either abandoned or resolved short of litigation. From my sample, only two of the 41 claims ended up in court. Both originated with administrative complaints lodged by Muscovites (meaning that two of the 26

\footnotetext{
${ }^{33}$ Housing shortages were endemic during the Soviet period. To ease the situation, large apartments were divided up to accommodate several families. Typically, each family would have a single room and all the families would share the kitchen and bathroom. Boym (1994:121-165) shares what it was like to live in these crowded spaces. A virtual museum of the communal apartment is available at http://kommunalka.colgate.edu/ (accessed on August 28, 2008). With the advent of the market, many of these communal apartments have been bought up by the "haves" within Russian society and been returned to their pre-revolutionary splendor. But some remain and, as Maria suggests, the residents tend to be the "have nots."
} 
Moscow claims ended with a lawsuit). The facts that underlie the two cases are similar. Both arise from ill-fated capital repair projects undertaken by $Z h K U$. Ivan was dissatisfied when mold began to grow on the wood that was brought into his apartment as part of $Z h K U$-sponsored renovations. ${ }^{34}$ By contrast, Tatyana was initially pleased with her repairs, but after two years, problems developed with the linoleum that had been installed. Though both ended up in court because they were unable to reach a settlement with their $Z h K U$, their motivations were quite different.

In many ways, Ivan is atypical. He actually enjoys litigation. Since retiring, he has initiated a number of lawsuits, always representing himself. As I noted earlier, he freely shared his newly-found legal expertise with the other focus group participants. In his own case, he took a number of actions when negotiating with $Z h K U$ that seemed aimed at infuriating them, including sending a petition to the procurator asking that a criminal case against the ZhKU be initiated. ${ }^{35}$ As he said, "I was corresponding with all the bosses." The lawsuit dragged on for five years. Ivan grumbled a bit about the toll on his health, but boasted about how it cost him nothing to bring this lawsuit. He told the other members of the focus group that the problems were ultimately remedied. It was not clear whether this was due to the outcome of the lawsuit, or whether he had simply outlasted the patience of the ZhKU representatives.

By contrast, Tatyana, a 52-year old x-ray technician, was a reluctant litigant. She found litigation to be expensive. To establish that the work done was flawed, she had to pay over 20,000 rubles (about $\$ 780$ ) to a licensed inspector. Then she had to hire a lawyer. She sought compensatory damages of 700,000 rubles (about \$27,300) and "moral" (or punitive) damages of 50,000 rubles (about $\$ 1950$ ). The lawyer had warned her that it would be a long haul, but she still complained about the endless delays, saying that "one time the other side failed to show up. The next time everyone showed up, but the judge had two cases carried over from the previous day. We all left with nothing for our troubles." She used up her vacation days in court. Even so, she did not regret her decision. She felt it was more a question of principle than of money. She was angry that the ZhKU was unwilling to acknowledge its responsibility. At the time of the focus group, the case had not yet been decided.

\section{Explaining the Evolution of Disputes in Russia}

The details of these two cases that ended up in court illustrate the critical role of personality. The specific facts of Ivan's case are indistinguishable from many others related over the course of the focus groups and are likely less compelling than many of those who did not go

\footnotetext{
${ }^{34}$ Ivan previously came to our attention, when he lectured his fellow focus group members about the substance of contract law (see pp. 16-17).

${ }^{35}$ When the procurator did not respond as he had hoped, Ivan sent a petition to then-President Putin.
} 
to court. His retired status gave him more free time, but none of the other pensioners in the focus groups had taken up litigation as a hobby. It was not his age, but his love of the fight that distinguished him from the other participants. At the other end of the spectrum, the fatalism that the Russian experience seems to breed also plays a role. This character trait seems particularly prevalent among women and was more pronounced in the Saratov groups than in the Moscow groups. Though the unintentional oversampling of women in Saratov may have skewed the results, the question of whether Russian women are more passive in the disputing context deserves further attention.

The different reaction of the various pensioners to similar stimuli suggests that age may matter less than I had expected at the outset. The very fact that the only two lawsuits were filed by people who are clearly part of a Soviet generation, indicates that those who lived through the "bad old days" do not necessarily shy away from mobilizing law and legal institutions when it serves their interests. At the same time, there were a number of focus group participants who came of age in the Soviet era who fit the stereotype and who would not go to court under any circumstances. Iurii, a 47-year old art critic is a good example. After listening to the story of how Tatyana ended up in court, Iurii responded:

The fact is that law doesn't work here. If an ordinary swindler takes an advance, knowing full well that his firm can't do the job, the firm will find some sort of justification - its lawyers will litigate it with you for years. It will be more expensive for you than them. As the saying goes, don't fight with the strong and don't sue the rich. This saying wasn't thought up by some group of scholars or politicians, but by ordinary people. ... You'd have to be a complete idiot to sue better to be smarter. Put together a brigade with recommendations from friends and acquaintances.

Nor did I find that younger people who had no memory of the Soviet legal system as adults were uniformly more prepared to mobilize law. A comparison of two of the participants in the younger group in Moscow is instructive. Recall Karina (see p. 20) who provoked the firm that erred when installing her air conditioner to replace the unit by threatening to file a lawsuit. The same group included Lidia, who seemed quite similar to Karina at first glance. Both were about the same age and had prestigious management jobs; both had university degrees; both had been to court in the past. But Lidia was determined never to repeat the experience. Much like the women in Saratov, she spoke of her intense dislike of conflict. She explained why she chose not to pursue a dispute over a kitchen renovation that hadn't turned out as planned:

I simply had no strength. That's how [the project] turned out. I understood how to complain. But I just don't feel like screaming and threatening every time. ... I have a sick child. I have problems at work and things don't always go smoothly with my husband. And in our country, going to court wastes your nerves. I know what it takes. I've been through it before. You can put together a pile of papers, but the money still ends up with the firm ... This is why I don't believe in courts. ... You don't end up with any money in the end. ... Moral [punitive] damages don't begin to compensate. The bottom line is that the game is not worth the 
candle. ${ }^{36}$ It's better to call and bitch someone out. Then you can live peacefully. Thus, members of the post-Soviet generation are not necessarily more open to using the courts. At least Lidia was willing to defend herself with the contractor, if not to initiate a lawsuit. At the opposite end of the spectrum, people of all generations exhibited a complete unwillingness to do anything. In the mixed-age Moscow focus group, this passivity, which dovetailed with their fatalism, was exhibited by women as young as 24 (Tamara) and as old as 50 (Galina).

These negative views about the Russian judicial system suggest that the reluctance to pursue disputes to the apex of the pyramid may stem from a deep distrust of the courts. The polling data certainly support this hypothesis. Most of the scholarly literature contends that this distaste for courts stems from the alleged corruption and politicization of the courts that persists as a legacy from the Soviet era (e.g., Ledeneva 2008). Though the focus groups were replete with criticisms of the courts, the sorts of comments made were mostly generic and not specific to the Russian case. Participants railed against the time and money needed to go to court. Many echoed Lidia's sentiments about how emotionally draining litigation can be. Natasha, a 37-year old musician from Moscow, who had endured a lengthy battle supporting her father's ultimately futile efforts to win his job back, commented that "one needs nerves of steel to appeal to the courts." She was gun-shy about going to court again, as were a number of veterans of the Russian courts. But that hardly makes Russia unusual. Litigation is difficult everywhere. It is rarely anyone's first choice as to how to resolve a dispute. The focus group discussion undermines the claim that Russian courts are somehow uniquely problematic and inherently unuseable. While it is true that, for the most part, these focus group participants did not use the courts, the reasons were similar to those voiced by people the world over (e.g., Silbey and Ewick 1998; Greenhouse, Yngvesson, and Engel 1994).

By this, I am not arguing that Russian courts are pristine, but rather that their politicization and corruption does not reach to the sorts of mundane cases that would have been brought by these focus group participants, and thus did not emerge as a significant factor in explaining the reluctance to litigate. The specter of corruption was a much more visible presence in the focus groups that dealt with personal injury. Many people who had been involved in traffic accidents spoke of the choice they had to make as to whether to bribe the police. Several also spoke passionately of their belief that the judges in their case had been swayed to ignore the law, either because the other side was politically connected or because they had been paid to do so. All of this supports a vision of Russia as having a dualistic legal system, where mundane cases are handled according to the law, but where there is an acceptance of outside interference, either to serve the political or economic interests of those with power. Moreover, ordinary Russians seem to appreciate this distinction and are able to adapt their behavior accordingly (Hendley forthcoming).

The role of lawyers in the evolution of these home repair disputes in Russia was peripheral. In contrast to Felstiner, et al.'s, description of the U.S. case, lawyers did not act as

\footnotetext{
${ }^{36}$ This is a Russian saying that conveys the meaning that it isn't worth the effort.
} 
transformational agents for most of those who pursued their claims. The only person who consulted a lawyer at the outset - Viktor - did so because the lawyer was an old friend (see pp. 19-20). His willingness to seek assistance from a lawyer did not connote a respect for the legal profession more generally. Like many of his compatriots, he had little faith, noting that "we know all too well how they are taught in legal institutes - who teaches there - whose money is in play. We live here; we know everything. Therefore simply to go a lawyer that you don't know and who has a diploma - that's a bad idea." Others supported him, saying that one should only hire a lawyer that has been recommended by a trusted friend. Another reason cited for not turning to lawyers for help was their cost. Several told of friends who had paid large sums to lawyers, but had gotten no discernable results. Once again, these sorts of sentiments are familiar to socio-legal scholars; they are not specific to Russia. In many other countries, however, people take counsel from lawyers, even though doing so is expensive, because they find value in this advice. Put differently, they find the legal system to be impenetrable without a learned guide. Perhaps the fact that most Russians do not view litigation as a viable option contributes to their diffidence toward lawyers.

If lawyers do not serve as transformational agents, then what factors are at play in the evolution of disputes? Felstiner, et al., emphasize fear of relational damage in explaining why the vast majority of disputes dissipate. Relational costs are not irrelevant in the Russian case, but play a more minor role than in the U.S. case. Where it was at issue, the key relationship was not between the disputing parties, but between the injured party and whomever had recommended the firm or workers who carried out the home repair project. Most of the focus group participants sought advice from friends, co-workers, and neighbors when undertaking home renovations. Connections (svyazy) have always been critical in Russia. In the Soviet era, having a strong web of connections or blat networks allowed people to negotiate around the restrictions of the planned economy, not just in the sphere of home repair, but in the more important areas of consumer goods and medical care (Ledeneva 1998). ${ }^{37}$ Indeed, connections were more important than money in the Soviet system, where the perennial shortages and the fixed prices meant that money could not necessarily provide access to goods or services. When someone allowed a friend access to their personal network, this was understood as a precious gift (that usually called for a return gift at some point in the future). Even if it did not work out as the friend had hoped, he would never do anything to undermine the original relationship. In present-day Russia, blat persists, albeit in a slightly different form (Ledeneva 2006). Connections remain a valuable

${ }^{37}$ Ledeneva (1988) struggles to define blat, noting that "everybody knows what blat is about but few grasp its essence. One reason is that the term means different things in different contexts" (p. 33). When pressed, she defines blat as"an exchange of "favours of access' in conditions of shortages and a state system of privileges," that "was often mediated and covered by the rhetoric of friendship or acquaintence" (p. 37). Acknowledging that it bore some resemblance to bribery, she draws on Crankshaw (1956: 74) to clarify the difference. He emphasizes that the motive for the exchange of favors under blat is self-defense and notes that "the most incorruptible individuals deal in it freely." Ledeneva concludes that "[b]ribery implies a conflict of interest where one is to be 'compensated' for doing something one would not do otherwise, while blat is a form of cooperation and mutual support with a long-term perspective, implying trust rather than compensation for risk" (1988: 40). 
currency, but with the introduction of market incentives, money has grown in importance. The question of when money trumps connections or vice versa is much debated. Among the focus group participants, several refrained from expressing their displeasure fully to those who had worked for them because they did not want to cause problems for their friends or co-workers who had originally recommended them. But the fact that so few cited this as a concern is a mark of how much things have changed since the collapse of the Soviet Union in the early 1990s. I suspect that the size of the venues for the focus groups played a role in minimizing this factor. Both Moscow and Saratov are large enough to support multiple vendors of almost any good or service, which lessens the value of one's connection to any particular vendor.

Another factor identified by Felstiner, et al., as having the potential to shape the evolution of disputes is the receptivity of the legal system to the underlying claim. Irrespective of the seriousness of the injury, as perceived by the affected party during the naming process, if the substantive law does not recognize the injury, then his ability to press for a remedy may be compromised. After all, even if the affected party has no plans to appeal to the courts and is seeking only to have the work redone to fix the problems, the other side's behavior may be colored by its awareness of the lack of legal remedies. This dynamic was at play in the focus groups. As detailed in the discussion of claiming, the participants were convinced that they could not take their claims to court if they did not have a written contract. In all of the groups, participants expressed regret at not pushing for a clear written contract at the outset. Some did not even have a written estimate (smeta). Echoing sentiments heard in many other countries, the participants spoke of feeling that they would be signaling a lack of trust for the firm or workers if they asked for something in writing. Valentina, one of the Moscow women discussed above who did not actively pursue her claim because she had no contract, blamed herself for not paying more attention to the legal niceties at the outset. She explained, "If everything isn't properly formulated, we have only ourselves to blame. ... Probably we're not trained to do this ..." Many said that they would insist on a written contract in their next home repair project.

Not all of the participants were sure that having had a contract would have helped them. Some argued that a contract would only help if they were prepared to take the dispute to court. And most were not, as evidenced by the comments of Inessa (her reluctance to claim was discussed above, see p. 12).

In what way can a contract protect me? I can appeal to the court if something doesn't suit me. But I totally don't want to do that. I can't even begin to understand the procedural rules. It's unpleasant; it's both my money and health. I'm not going to court. I can't even imagine myself in court. It's a question of time, nerves, and health.

The sense among the participants was that having a contract was a necessary, but not sufficient, condition to ensuring a smooth home repair experience. Some worried that contracts could be a trap; that they look fine on the surface, but often contain loopholes that protect the contractors at the expense of the home owners. Valentina, commented: "in every contract, there are submerged reefs and one has to navigate around them." Along the same lines, some doubt was expressed as to whether people like them, without any legal education, could make sense of contracts. This 
was hardly a Moscow-centric view, as this lively exchange between two Saratov doctors illustrates:

$\underline{\text { Liubov }}^{38}$ : You know, we don't know our rights. Some people might draw up a contract, but you'd need to take it to a lawyer who can study the contract and tell you where the problems are. I don't understand any of this. I sign the contract blindly. If I was to take every contract for every insignificant repair project to my lawyer, then I won't have enough money left to do the repairs.

Svetlana: I think you've put your finger on the heart of the problem. Here [in Russia] you don't need to have legal education or a lawyer friend to be convinced of the correctness of the contract. The heart of the problem is our laziness. We lack the desire to read the contract, to dig into the substance of the matter, to think about the consequences. ... But above all, the problem is laziness. No one ever bothers to read the contract. This is our own fault. The other side writes it and tells us - please read it carefully. But it's easier for us to say - I trust you.

Liubov: When I read a contract, I don't understand anything that is written.

Svetlana: Because you don't read it carefully. When the contract is presented to you, you probably have no time. You could say - ok, let me study it. If you read it carefully, you would understand everything. But if you take the easy way out, then you get what you deserve, like most of us.

For those who study contractual behavior, this sort of exchange is familiar. But in Russia, as elsewhere, people's beliefs about the viability of a claim or about their own ability to understand the terms of contracts are important because they shape behavior, even when they are baseless.

This last exchange, as well as many of the other comments of the focus group participants, brings the question of Russian legal culture to the fore. ${ }^{39}$ A theme that ran through all of the focus groups was the lack of knowledge about law and the legal system among the Russian citizenry. Typically it was expressed as a low level of "legal literacy" (pravovaia gramotnost'). Those unfamiliar with contemporary Russia might assume that information about substantive law and about the procedural rules that govern the courts are inaccessible to the populace. This was the case during the decades of Soviet power. But for the past few decades, Russians have been inundated with information. Copies of statutory codes and commentaries to statutory codes are easily available at bookstores and libraries. If the legalese of these materials makes them frightening to laymen, then there are also a plethora of books in the vein of "law for dummies," that assume no prior knowledge. In addition, the Russian-language web contains a wealth of information about law, including a free search engine for legal information (akin to

\footnotetext{
${ }^{38}$ Liubov was discussed previously (see pp. 11-12) as someone who was unwilling to name her injury.

${ }^{39}$ Kurkchiyan (2009:338) reminds us that there has been little research on Russian legal culture.
} 
LEXIS). ${ }^{40}$ There are also websites that provide form contracts for almost any purpose, including home repairs. ${ }^{41}$ Thus, transparency is not the problem. But it was a problem in the Soviet era when access was tightly controlled. It may be that people have not yet adjusted themselves to the new conditions. The more likely explanation, given that these new conditions have been present since at least 1990, is that Russians have chosen not to pay attention to this information, which lends credence to the laziness explanation put forward by Svetlana. ${ }^{42}$ To be fair, many Russians were hit hard by the economic dislocation that accompanied the transition to the market in the 1990s. In all likelihood, they were preoccupied with keeping their heads above water and had little time to keep up with the never-ending changes in the legal system. Yet the economy has been relatively stable under Putin and, as the focus groups reveal, legal literacy remains low. Perhaps President Medvedev's campaign to fight what he has described as "legal nihilism" will make a difference, but few Russians are optimistic. There is simply no tradition of paying attention to these matters. By contrast, there is a long tradition about complaining about how law does not adequately protect citizens that ties into the fatalism that underlies Russian culture more generally.

One final factor that appears to affect the transformation of disputes is location. As Table 3 demonstrates, the likelihood of naming is fairly equal as between Moscow and Saratov. But as we proceed up the pyramid of disputing, Muscovites emerge as more contentious. They were more likely to blame and to claim than were their Saratov counterparts. To some extent, the glitches in recruiting for the focus groups in Saratov may be driving these results. The Saratov groups were made up almost entirely of women. ${ }^{43}$ More importantly, the projects undertaken by these women were less substantial than the projects of the Moscow focus group participants. Both of these factors may have contributed to the apparent reticence of the Saratov participants. But assuming that the variation is genuine, a number of explanations may be at play.

${ }^{40}$ The introduction of market incentives gave rise to several search engines along the lines of LEXIS. Konsul'tant plius (http://www.consultant.ru/online/) is available free of charge and provides easy access to legislation, regulations, and judicial opinions. Two others legal search engines, Kodeks (http://www.kodeks.ru/) and Garant (http://www.garant.ru/), require a subscription.

${ }^{41}$ Some websites have been set up by lawyers and require payment to access form contracts. Others provide form contracts at no cost. E.g., http://www.dogovor.partnerstvo.ru/ (accessed on August 30, 2008); http://biz.lpros.ru/10.htm (accessed on August 30, 2008).

${ }^{42}$ In their November 2007 survey on the work of the courts, VTsIOM asked Russians how they got information about the courts. Respondents were free to pick all the answers that applied to them. The most common answer was central television ( 42 percent), followed by talking with friends and relatives (26 percent). Only 2 percent said they got their information via the internet. "Otsenka deyatel'nosti sudov v Rossiiskoi Federatsii" (http://wciom.ru/novosti/otkrytye-proekty/ocenka-dejatelnosti-sudov-v-rf.html, accessed on July 21, 2008).

${ }^{43}$ Whether Russian women are less conflict oriented cannot be definitely established on the basis of this small sample, but the extent to which they self-identified as conflict-resistant suggests a hypothesis that is worth pursuing. 
Explanations that are grounded in the perception that governmental institutions, including courts, are thought to be staffed by the cream of the crop in Moscow, suggesting that Moscow institutions may enjoy greater legitimacy than those in the periphery of Russia are not terribly compelling. After all, only two Muscovites took their claims to the courts. Most of the claims were resolved through negotiations between the injured party and the firm or workers who carried out the project. This forces us back onto the conventional wisdom about Muscovites, which holds that they are more sophisticated and less willing to take guff from anyone. Muscovites tend to look down on their country cousins, and those many of those who are not from Moscow have internalized this second-class status. This explanation of the regional variation is not terribly satisfactory. These differential outcomes deserve further analysis.

\section{Conclusions}

What can be concluded about the willingness of Russians to mobilize law to defend their interests? The focus on home repair projects provided a window into the process by which disagreements between ordinary Russians evolve into full-fledged disputes. Home repair problems rarely attract the attention of the rich or politically powerful, which largely eliminates the fear of judicial manipulation as a motivating force. Instead, we can concentrate on the choices made by Russians who have been disappointed by the outcome of their projects.

While the focus group methodology renders any conclusions necessarily tentative, the analysis permits a ground-level view of Russian reality and provides a basis for further research. At first glance, the results seem to confirm the common wisdom about the resistance of Russians to using law on their own behalf. After all, only two of the 84 home repair projects discussed ended up in court, and just a handful more threatened litigation as a means of encouraging settlement. ${ }^{44}$ But a closer look reveals that many more of the participants took law into account in formulating their strategies. They may not have always done so explicitly. Indeed, they may not even have been aware that law was part of the equation for them, but it was. More often than not, law was a factor that discouraged them from pursuing their disputes. For example, for all of those who failed to claim or who put forward a half-hearted claim because they had no written contract, perceptions about law acted as a brake on their behavior. Likewise, for those who did not want to press forward because they had no stomach for litigation, law was relevant. While the end result is what the social science literature would have predicted, namely a reluctance to go to court, the reasons are not due to a cultural predilection to go around the law, as the literature suggests.

${ }^{44}$ This statistic would be more meaningful if it could be put in a broader comparative context. The paucity of empirical studies that trace the evolution of disputes makes this difficult. Using the framework developed by Felstiner, et al., to study disputing behavior in the U.S., Trubek et al. (1983: 8687 , found that " $71.8 \%$ of individuals with grievances complained to the offending party, and that a dispute arose in $63 \%$ of those situations. Of these disputes, $11.2 \%$ resulted in a court filing." They concluded that "it is clear that litigation ... is by no means the most common response to disputes." 
Indeed, in many ways, the basic contours of the disputing pyramid revealed by the research is quite similar to that found in other settings. When faced with problems, Russians are generally prepared to name their injury and to blame the person or firm who caused the harm. When it comes to claiming, however, Russians become more skittish. This fits with what has been observed elsewhere. People are naturally more reticent when the process requires them to interact with the wrongdoer. Often it is easier to "lump" the dispute than to risk an unpleasant encounter. Opting out is more likely - in Russia as elsewhere - when the injury suffered is considered insignificant, due either to the small amount at stake or the triviality of the inconvenience suffered. What seems unusual about the Russian case is the propensity to shift blame from the contractors onto themselves. Their rationale that they share blame because they failed to monitor the workers closely enough or because they fed them too well (or not well enough) seems rather flimsy and may hide a reluctance to confront. From the available data, this tendency to eschew conflict seems correlated with gender, but whether that will stand up to more rigorous research remains to be seen.

Perhaps the most surprising finding is the unimportance of relationships in explaining the ratcheting up of disagreements into disputes in Russia. Russia is a country where connections have long been thought of as a currency more valuable than money. Most people took advantage of these connections to locate the workers or firms they used for their home repair projects, asking friends, relatives, and/or co-workers for recommendations. Those who were satisfied with their home repair experiences attributed it to the strength of the relationships they established with the workers. But few of those who had problems expressed any fear of damaging their relationships with workers. Any concern with preserving connections focused on the potential danger of undermining relationships with the original recommenders. At the same time, when problems arose, few cited a fear of damaging these pre-existing relationship as a factor to be considered when deciding whether to pursue the dispute. This may reflect both the diminishing power of blat and the fungibility of construction firms. There is little doubt that if similar research had been carried out during the Soviet era, respondents would have been much less casual about the potential damage to their networks. The rise of the market has caused construction firms to sprout up like mushrooms, rendering them somewhat interchangeable.

The legendary Russian fatalism, which has seen them through centuries of tsarist rule and decades of Communist domination, colors the attitudes and behavior of Russians in the legal realm. As Kurkchiyan (2003:30) has argued, "the negative myth of the rule of law is dominant." Russians expect the worse and are always surprised by positive outcomes, both with regard to legal disputes and more generally. Given that, the willingness of so many of them to go after their contractors in the wake of disappointing home repair projects is perhaps the biggest surprise. 
Table 1: Attributes of Focus Groups

\begin{tabular}{|l|c|c|c|l|c|}
\hline & N & $\begin{array}{c}\text { Mean } \\
\text { Age }\end{array}$ & Gender & Education & $\begin{array}{c}\text { Prior Court } \\
\text { Experience? (1) }\end{array}$ \\
\hline Moscow Older Group & 10 & 49 & $\begin{array}{c}\mathrm{M}=50 \% \\
\mathrm{~F}=50 \%\end{array}$ & $\begin{array}{l}\text { Completed University: } 90 \% \\
\text { Completed High School: } 10 \%\end{array}$ & $40 \%$ \\
\hline Moscow Younger Group & 11 & 31 & $\begin{array}{c}\mathrm{M}=45.5 \% \\
\mathrm{~F}=54.5 \%\end{array}$ & Completed University: 100\% & $45.5 \%$ \\
\hline $\begin{array}{l}\text { Moscow Mixed-Age } \\
\text { Group }\end{array}$ & 10 & 46 & $\begin{array}{c}\mathrm{M}=30 \% \\
\mathrm{~F}=70 \%\end{array}$ & $\begin{array}{l}\text { Completed University: } 80 \% \\
\text { Completed High School: } 20 \%\end{array}$ & $40 \%$ \\
\hline Saratov Older Group & 10 & 37.6 & $\begin{array}{c}\mathrm{M}=0 \% \\
\mathrm{~F}=100 \%\end{array}$ & $\begin{array}{l}\text { Completed University: } 20 \% \\
\text { Completed High School: } 80 \%\end{array}$ & $70 \%$ \\
\hline Saratov Younger Group & 9 & 30.9 & $\begin{array}{c}\mathrm{M}=0 \% \\
\mathrm{~F}=100 \%\end{array}$ & $\begin{array}{l}\text { Completed University: } 77.8 \% \\
\text { Unfinished High School: } 22.2 \%\end{array}$ & $22.2 \%$ \\
\hline $\begin{array}{l}\text { Saratov Mixed-Age } \\
\text { Group }\end{array}$ & 9 & 34.2 & $\begin{array}{c}\mathrm{M}=22.2 \% \\
\mathrm{~F}=77.8 \%\end{array}$ & $\begin{array}{l}\text { Completed University: } 22.2 \% \\
\text { Completed High School: } 77.8 \%\end{array}$ & $22.2 \%$ \\
\hline
\end{tabular}

(1) The focus group participants were asked whether they had had any experience in court. Those who responded positively might have been the plaintiff or defendant in a case, or they might have been a witness in someone else's case. 
Table 2: Information about Focus Group Participants Referenced in the Article

\begin{tabular}{|c|c|c|c|c|c|}
\hline & Name & Age & Education & Occupation & $\begin{array}{c}\text { Court } \\
\text { Experience? }\end{array}$ \\
\hline \multicolumn{6}{|c|}{ Moscow Older Group } \\
\hline & Alla & 57 & University degree & Pensioner & No \\
\hline & Feliks & 43 & University degree & Real estate agent & Yes \\
\hline & Ivan & 61 & University degree & Pensioner & Yes \\
\hline & Kamal & 37 & University degree & Geneticist & No \\
\hline & Katya & 38 & High school degree & Housewife & No \\
\hline & Marina & 58 & University degree & Economist & Yes \\
\hline & Sofia & 49 & University degree & Engineer & No \\
\hline & Valentina & 43 & University degree & Administrator & Yes \\
\hline \multicolumn{6}{|c|}{ Moscow Younger Group } \\
\hline & Elena & 35 & University degree & Administrator & No \\
\hline & Evgeniia & 31 & University degree & Administrator & Yes \\
\hline & Karina & 31 & University degree & Doctor & Yes \\
\hline & Lidia & 35 & University degree & $\begin{array}{l}\text { Vice president of } \\
\text { industrial factory }\end{array}$ & Yes \\
\hline & Natasha & 37 & University degree & Musician & Yes \\
\hline & Roman & 31 & University degree & Programmer & No \\
\hline \multicolumn{6}{|c|}{ Moscow Mixed-Age Group } \\
\hline & Dmitrii & 49 & University degree & Entrepreneur & Yes \\
\hline & Galina & 56 & University degree & Professor & Yes \\
\hline & Iurii & 47 & University degree & Art critic & No \\
\hline & Margarita & 50 & High school degree & Library worker & No \\
\hline & Mark & 47 & University degree & Fashion designer & No \\
\hline
\end{tabular}




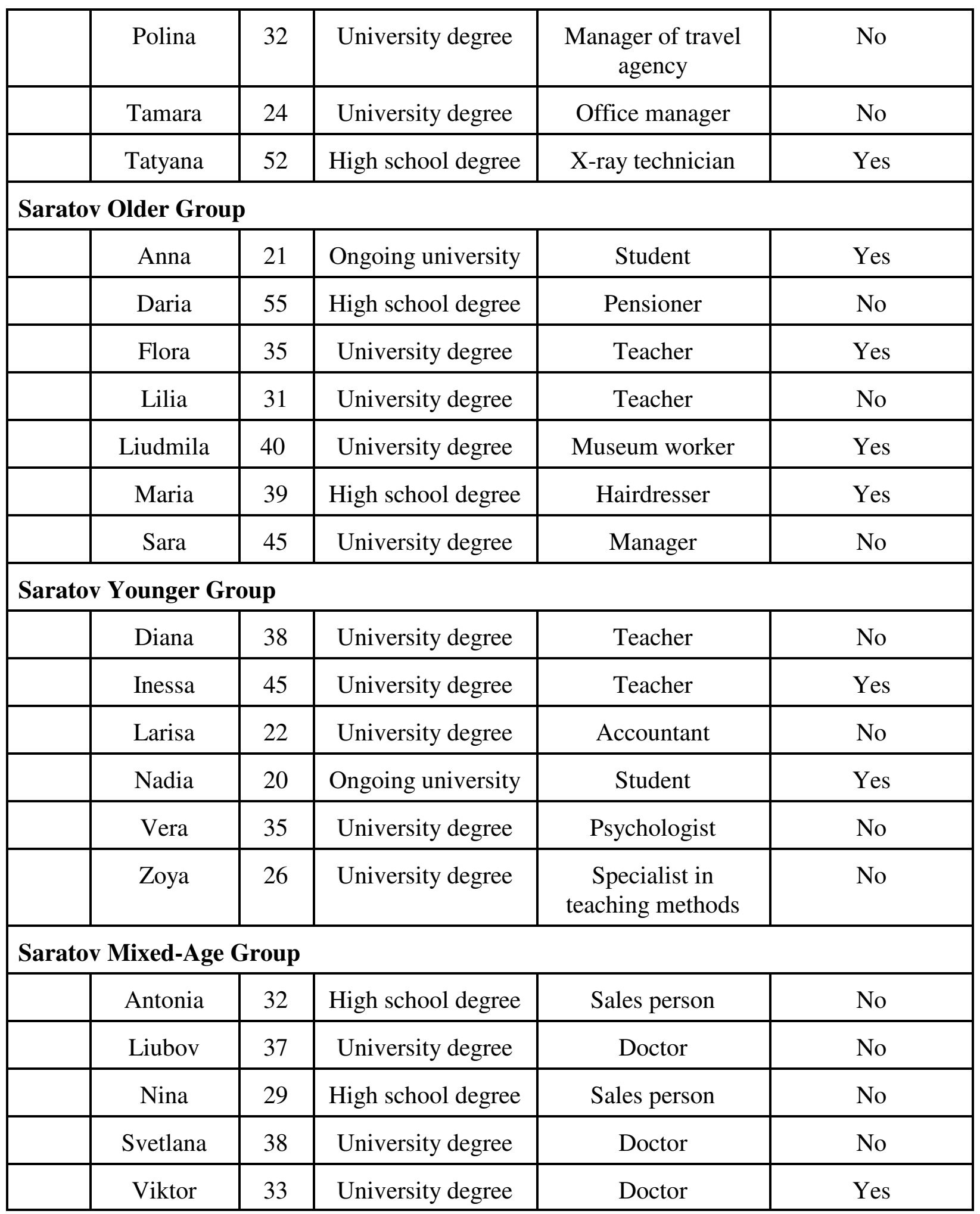


Table 3: Overview of Evolution of Home Repair Disputes

\begin{tabular}{|l|c|c|c|c|}
\hline & Total N & $\begin{array}{c}\text { Naming (as \% } \\
\text { of Total N) }\end{array}$ & $\begin{array}{c}\text { Blaming (as \% } \\
\text { of Naming) }\end{array}$ & $\begin{array}{c}\text { Claiming (as \% of } \\
\text { Blaming) }\end{array}$ \\
\hline All Groups & 84 & $71(84.5 \%)$ & $62(87 \%)$ & $41(66 \%)$ \\
\hline Moscow Groups & 49 & $42(85.7 \%)$ & $38(90 \%)$ & $26(68 \%)$ \\
\hline Saratov Groups & 36 & $29(83 \%)$ & $24(83 \%)$ & $15(54 \%)$ \\
\hline
\end{tabular}




\section{Bibliography}

Albiston, Catherine R. "Bargaining in the Shadow of Social Institutions: Competing Discourses and Social Change in Workplace Mobilization of Civil Rights," Law \& Society Review, 39:1, pp. 11-49, 2005.

Boym, Svetlana. Common Places: Mythologies of Everyday Life in Russia. Cambridge, MA: Harvard University Press, 1994.

Crankshaw, Edward. Russia Without Stalin. London: Michael Joseph, 1956.

Eisenberg, Theodore. "Negotiation, Lawyering, and Adjudication: Kritzer on Brokers and Deals." Law \& Social Inquiry, 19:1, pp. 275-99, 1994.

Ellickson, Robert C. Order Without Law: How Neighbors Settle Disputes. Cambridge: Harvard University Press, 1991.

Engel, David M. "Globalization and the Decline of Legal Consciousness: Torts, Ghosts, and Karma in Thailand," Law \& Social Inquiry, 30:3, pp. 469-514, 2005.

Engel, David M., and Frank W. Munger. Rights of Inclusion: Law and Identity in the Life Stories of Americans with Disabilities. Chicago: University of Chicago Press, 2003.

Ewick, Patricia, and Susan S. Silbey, The Common Place of Law: Stories from Everyday Life. Chicago: University of Chicago Press, 1998.

Feifer, George. Justice in Moscow. New York: Simon \& Schuster, 1964.

Felstiner, William L.F., Richard L. Abel, and Austin Sarat. "The Emergence and Transformation of Disputes: Naming, Blaming, Claiming ...” Law \& Society Review, 15:3-4, pp. 631-54, 198081.

Greenhouse, Carol J., Barbara Yngvesson, and David M. Engel. Law and Community in Three American Towns. Ithaca: Cornell University Press, 1994.

Griffiths, John. "What Do Dutch Lawyers Actually Do in Divorce Cases?" Law and Society Review, 20:1, pp. 135-67, 1986.

Hale, Henry. Why Not Parties in Russia? Democracy, Federalism, and the State. Cambridge: Cambridge University Press, 2005.

Hay, Jonathon R., and Andrei Shleifer, "Private Enforcement of Public Laws: A Theory of Legal Reform," American Economic Review, 88:2, pp. 398-403, 1998. 
Hendley, Kathryn. "Assessing the Rule of Law in Russia," Cardozo Journal of International \& Comparative Law, 14:2, pp. 347-91, 2006.

Hendley, Kathryn. "Beyond the Tip of the Iceberg: Business Disputes in Russia," in Assessing the Value of Law in Transition Economies, pp. 20-55, edited by Peter Murrell. Ann Arbor: University of Michigan Press, 2001.

Hendley, Kathryn. "Enforcing Judgments in Russian Economic Courts," Post-Soviet Affairs, 20:1, pp. 46-82, 2004.

Hendley, Kathryn. “'Telephone Law' and the 'Rule of Law:' The Russian Case,” Hague Journal of the Rule of Law, 1:2, forthcoming, 2009.

Kritzer, Herbert M. The Justice Broker: Lawyers and Ordinary Litigation. New York: Oxford University Press, 1990.

Kurkchiyan, Marina. "The Illegitimacy of Law in Post-Soviet Societies," in Law and Informal Practices: The Post-Communist Experience, pp. 25-46, edited by Denis J. Galligan and Marina Kurkchiyan. Oxford: Oxford University Press, 2003.

Kurkchiyan, Marina. "Russian Legal Culture: An Analysis of Adaptive Response to an Institutional Transplant." Law \& Social Inquiry, 39:2, pp. 337-364, 2009.

Ledeneva, Alena. How Russia Really Works: The Informal Practices That Shaped Post Soviet Politics and Business. Ithaca, N.Y.: Cornell University Press, 2006.

Ledeneva, Alena. Russia's Economy of Favours: Blat, Networking and Informal Exchange. Cambridge: Cambridge University Press, 1998.

Ledeneva, Alena V. “Telephone Justice in Russia.” Post-Soviet Affairs, 24:4, pp. 324-350, 2008.

Merry, Sally Engle. Getting Justice and Getting Even: Legal Consciousness Among WorkingClass Americans. Chicago: University of Chicago Press, 1990.

Sarat, Austin, and William L.F. Felstiner. "Law and Strategy in the Divorce Lawyer's Office." Law and Society Review, 20:1, pp. 93-132, 1986.

Sharlet, Robert: "Stalinism and Soviet Legal Culture" in Stalinism: Essays in Historical Interpretation, pp. 155-79, edited by Robert C. Tucker. New York: W.W. Norton, 1977.

Trubek, David M., William L.F. Felstiner, Herbert M. Kritzer, and Joel B. Grossman. "The Costs of Ordinary Litigation." UCLA Law Review, 31:1, pp. 72-123, 1983. 
Varese, Federico. The Russian Mafia: Private Protection in a New Market Economy. Oxford: Oxford University Press, 2001. 